\title{
Identification of a protein associated with the activity of cytokine-induced killer cells
}

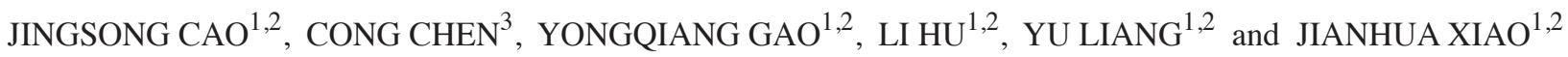 \\ ${ }^{1}$ Institute of Pathogenic Biology, Medical College, Hunan Provincial Key Laboratory for Special Pathogens \\ Prevention and Control; ${ }^{2}$ Hunan Province Cooperative Innovation Center for Molecular Target New Drug Study; \\ ${ }^{3}$ Laboratory Department, The Second Hospital, University of South China, Hengyang, Hunan 421001, P.R. China
}

Received April 26, 2016; Accepted July 14, 2017

DOI: $10.3892 / \mathrm{ol} .2017 .7042$

\begin{abstract}
Cytokine-induced killer cells (CIKs) adoptive immunotherapy for efficient antitumor ability is used clinically, but details regarding the proteins associated with CIK activity remain unclear. In the current study, the cytotoxicity of CIKs on hepatoma was identified to be significantly downregulated by 1.61-fold following gentamincin treatment. Further research revealed that a differentially expressed protein (P43) was significantly downregulated by 1.22 -fold using one-dimensional gel electrophoresis analysis. Of these, the P43 was identified as human haptoglobin using liquid chromatography-mass spectrometry. Western blotting demonstrated that the haptoglobin specifically reacted with rabbit anti-human-haptoglobin. Furthermore, western blotting results verified that the haptoglobin was significantly downregulated by 1.17 -fold compared with the control group. In addition, the expression of haptoglobin mRNA was significantly downregulated by 1.73 -fold following gentamincin treatment. Taken together, the results of the present study demonstrated that the expression of haptoglobin protein was associated with the activity of CIKs, and the results will be beneficial to the further investigation of CIK activity-enhancement mechanism.
\end{abstract}

\section{Introduction}

Adoptive immunotherapy is an effective and safe anticancer therapy (1), and currently used for various tumor treatments, including renal cell carcinoma (2), lung cancer (3), breast cancer (4), melanoma (5), and hepatoma (6).

Correspondence to: Professor Jianhua Xiao, Institute of Pathogenic Biology, 5 Building, Medical College, Hunan Provincial Key Laboratory for Special Pathogens Prevention and Control, University of South China, 5 Changsheng West Road, Hengyang, Hunan 421001, P.R. China

E-mail: jhxiao223@163.com

Key words: cytokine-induced killer cells, related activity protein, haptoglobin, activity-enhancing mechanism, liquid chromatographymass spectrometry
As a valuable cancer therapeutic scheme, numerous studies focused on $\mathrm{T}$ cells in order to further improve the antitumor activity of adoptive immunotherapy (1). Rettinger et al (7) and Meng et al (8) demonstrated that IL-15 and IL-21, respectively were able to promote the proliferative, and cytotoxic activity of cytokine-induced killer cells (CIKs). Rutella et al (9) noted that thymoglobulin efficiently expanded the CIK population, and that the CIKs generated by thymoglobulin were feasible and safe for solid tumor treatment. Tan et al (10) verified that K-ras dendritic cells were able to enhance CIK proliferation and increase the killing effect on pancreatic cancer cells. Though the activity of CIKs may be enhanced by technological strategies, maneuvers to improve the antitumor efficacy through the use of $\mathrm{T}$ cells have been under exploration (11). However, the proteins associated with CIK activity remain unclear.

In the present study, it was demonstrated that the cytotoxicity of CIKs was significantly influenced following gentamicin treatment. Further research verified that a protein identified by proteomic and reverse transcription-quantitative polymerase chain reaction (RT-qPCR) strategies was associated with CIK activity. The results of the current study have important implications for the investigation of the CIK activity-enhancement mechanism.

\section{Materials and methods}

CIK culture and protein extraction. Peripheral blood was donated from a 31-year-old male volunteer following written informed consent being obtained. The present study was approved by the Animal Welfare and Research Ethics Committee of the Institute of University of South China (Hengyang, China).

Lymphocytes were separated and cultured as reported by Pan et al (12), and Laport et al (13) with certain modifications. Equivalent volumes of peripheral blood and $0.9 \%$ physiological saline were mixed followed with ficoll gradient separation (LymphoPrep; PAA Laboratories; GE Healthcare, Chicago, IL, USA). Following centrifugation at $800 \mathrm{x}$ g for $20 \mathrm{~min}$ at room temperature, the leukocyte layer was collected and washed twice with $0.9 \%$ physiological saline. Following centrifugation at $500 \mathrm{x} \mathrm{g}$ for $7 \mathrm{~min}$ at room temperature, the cells cultured with gentamicin $(80 \mathrm{U} / \mathrm{ml}$; Yichang Humanwell Pharmaceutical Co., Ltd., Yichang, China) were defined as the 
experiment group, and the cells cultured with no gentamicin were defined as the control group. The lymphocytes were cultured in GT-T551 medium (Takara Biotechnology Co., Ltd., Dalian, China) with 1,000 U/ml $\gamma$-interferon (Beijing Biocoen Biotechnology Co., Ltd., Beijing, China) and $10 \%$ autologous plasma added on day 0 . Then, $50 \mu \mathrm{g} / \mathrm{ml}$ CD3 monoclonal antibody (catalogue no. Mab-37; Skoda Biotechnology Co., Ltd., Shanghai, China) and $100 \mathrm{U} / \mathrm{ml}$ interleukin $1 \alpha$ PeproTech China, Suzhou, China) were added on day 1. Subsequently, $1,000 \mathrm{U} / \mathrm{ml}$ recombinant human interleukin 2 (SL Pharma Labs, Inc., Wilmington, DE, USA) and 2\% autologous plasma were added to the medium from day 1 onward. The cells were cultured at $37^{\circ} \mathrm{C}$ with $5 \% \mathrm{CO}_{2}$ until the 11 th day.

The CIK protein was extracted as reported by Gao et al (14) with certain modifications. The CIKs were centrifuged at $150 \mathrm{x}$ g for $10 \mathrm{~min}$ at $4^{\circ} \mathrm{C}$, and the precipitate was washed with $1 \mathrm{ml} 0.9 \%$ physiological saline three times. After resuspension in $0.1 \mathrm{ml} 0.9 \%$ physiological saline, the CIKs were lysed by freezing-thawing from $-80^{\circ} \mathrm{C}$ to room temperature five times, and then centrifuged at $13,000 \mathrm{x}$ g for $10 \mathrm{~min}$ at $4^{\circ} \mathrm{C}$. After determining the protein concentration using the Bradford method (15), the supernatant was collected and stored at $-20^{\circ} \mathrm{C}$ with $1 \mathrm{Mm}$ phenylmethanesulfonyl fluoride (Sigma-Aldrich; Merck KGaA, Darmstadt, Germany) for subsequent analysis.

Flow cytometry analysis. A total of $1 \mathrm{ml} \mathrm{CIK}$ suspension was collected following centrifugation at $150 \mathrm{x} \mathrm{g}$ for $10 \mathrm{~min}$ at room temperature, the precipitate was resuspended in $1 \mathrm{ml}$ of $0.9 \%$ physiological saline and centrifuged at $150 \mathrm{x}$ g for $10 \mathrm{~min}$ at room temperature. The precipitate was then resuspended in $150 \mu 10.9 \%$ physiological saline and divided into two groups. One group as the isotype control with FITC mouse IgG $2 \alpha$ (5 $\mu \mathrm{l}$; catalogue no. 555573; BD Biosciences, Franklin Lakes, NJ, USA) added, and the control or experiment groups had FITC mouse anti-human CD3 (5 $\mu$ i; catalogue no. 555339; BD Biosciences) added. The three groups were all incubated $15 \mathrm{~min}$ at room temperature, then resuspended in $1 \mathrm{ml} 0.9 \%$ physiological saline, and centrifuged at $150 \mathrm{x} \mathrm{g}$ for $10 \mathrm{~min}$ at room temperature. Finally, the precipitate was resuspended in $0.2 \mathrm{ml} 0.9 \%$ physiological saline, and prepared for analysis using a BD Accuri C6 flow cytometer (BD Biosciences).

MTT analysis. The HepG2 hepatoma cell line, which was purchased from the Advanced Research Center of Central South University (Changsha, China), was cultured in Dulbecco's modified Eagle's medium (Thermo Fisher Scientific, Inc., Waltham, MA, USA) supplemented with 10\% FBS (Thermo Fisher Scientific, Inc.) at $37^{\circ} \mathrm{C}$ and in $5 \% \mathrm{CO}_{2}$. Hepatoma cells used as target cells were obtained at the logarithmic growth phase and the concentration was adjusted to $4 \times 10^{4}$ cells $/ \mathrm{ml}$. CIKs cultured for 11 days were used as effector cells and mixed with target cells in the ratio 40:1 (effector cell:target cell). A total of $10 \mathrm{ml} \mathrm{CIK}$ culture medium was collected following centrifugation at $150 \mathrm{x} \mathrm{g}$ for $10 \mathrm{~min}$ at room temperature. The precipitate was resuspended in GT-T551 containing 2\% autologous plasma and diluted to $1.6 \times 10^{6}$ cells $/ \mathrm{ml}$. The suspension was divided into three groups: The effector-target group, $100 \mu \mathrm{l}$ effector and target cells; effector cell group, $100 \mu \mathrm{l}$ effector cells and GT-T551 culture medium; target cell group, $100 \mu 1$ target cells and GT-T551 culture medium. All groups
Table I. Nucleotide sequences of primers

\begin{tabular}{ll}
\hline Primer $^{\mathrm{a}}$ & \multicolumn{1}{c}{ Sequence (5'-3') } \\
\hline Haptoglobin-F & CAGCCAGAAACATAACCC \\
Haptoglobin-R & TCTACACCCTAACTACTCCC \\
$\beta$-actin-F & ATCGTGCGTGACATTAAGGAG \\
$\beta$-actin-R & TAGGTGCTTTGATGGAAGTTGAG
\end{tabular}

${ }^{\text {aThe }}$ primers of haptoglobin were designed according to its cDNA sequence (GenBank: K00422.1). F, forward; R, reverse.

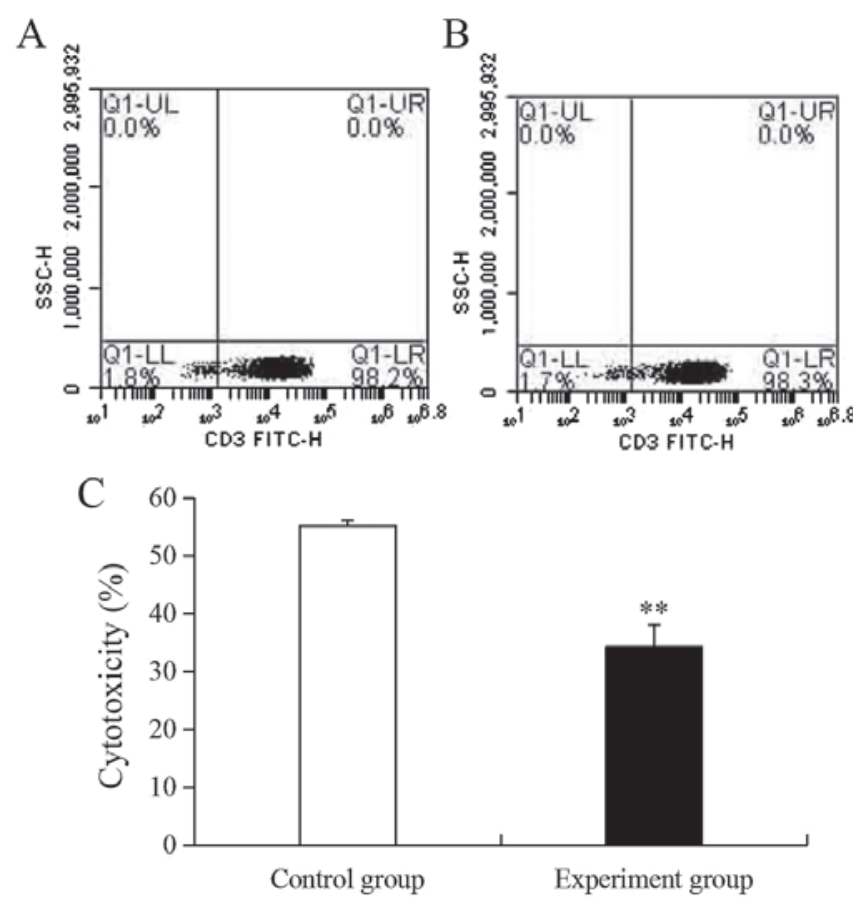

Figure 1. Cytokine-induced killer cells purity and activity analyzed by flow cytometry and MTT methods. The ratio of the $\mathrm{CD}^{+}$subtype in the (A) control group and (B) experiment group by flow cytometry. (C) Antitumor activity of T cells on hepatoma cells investigated using an MTT assay. Bars represent mean + standard deviation. $(\mathrm{n}=3){ }^{*}{ }^{* *} \mathrm{P}<0.01 . \mathrm{CD}$, cluster of differentiation.

were cultured at $37^{\circ} \mathrm{C}$ and $5 \% \mathrm{CO}_{2}$ for $24 \mathrm{~h}$. A total of five parallel experiments were used in each group. Then, $10 \mu \mathrm{l}$ MTT $(5 \mathrm{mg} / \mathrm{ml})$ was added and cultured at $37^{\circ} \mathrm{C}$ with $5 \% \mathrm{CO}_{2}$ for $4 \mathrm{~h}$. Following centrifugation at $900 \mathrm{x}$ g for $5 \mathrm{~min}$ at room temperature, the precipitate was dissolved with $100 \mu 1 \mathrm{DMSO}$, agitated for $15 \mathrm{~min}$ at $37^{\circ} \mathrm{C}$, and the optical density (OD) was detected at $490 \mathrm{~nm}$. The killing rate $(\%)$ was calculated as follows: $\left[1-\left(\mathrm{OD}_{\text {effector-target cell well }}-\mathrm{OD}_{\text {effector cell well }}\right) / \mathrm{OD}_{\text {target cell }}\right.$ well $\mathrm{x} 100 \%$.

One-dimensional gel electrophoresis (1-DE) analysis. 1-DE was performed using a 5\% stacking gel ( $\mathrm{pH}$ 6.8) and an $8 \%$ separating gel ( $\mathrm{pH} 8.9)$ in Tris-glycine buffer $(\mathrm{pH} 8.3)$, and $10 \mu \mathrm{g}$ protein was analyzed. The gels were run at $60 \mathrm{~V}$ for $45 \mathrm{~min}$, then $120 \mathrm{~V}$ for $2-3 \mathrm{~h}$ per gel in an ice-bath until the bromophenol blue dye had migrated to $<1 \mathrm{~cm}$ from the bottom of the gel. Subsequently, The gels were stained with coomassie 

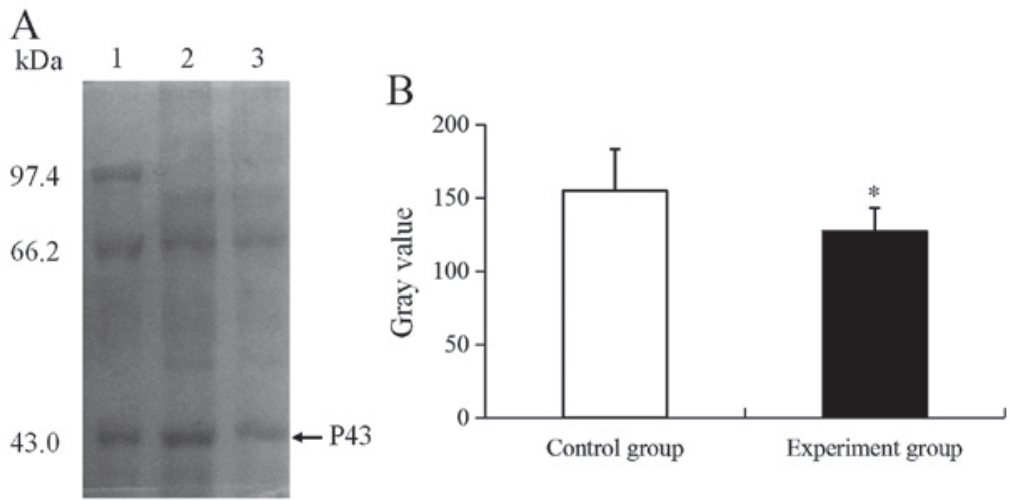

Figure 2. 1-DE was used to identify differentially expressed proteins in cytokine-induced killer cells. (A) 1-DE analysis of P43 protein: Lane 1, molecular mass markers; lane 2, control group; lane 3 , experiment group. (B) The histogram analysis of gray values. Bars represent mean + standard deviation. $\left(\mathrm{n}=3\right.$ ). ${ }^{*} \mathrm{P}<0.05$. 1-DE, One-dimensional gel electrophoresis.

brilliant blue R-250 at room temperature for $15 \mathrm{~min}$. The bands was analyzed using Quantity One 4.6.2 (Bio-Rad Laboratories, Inc., Hercules, CA, USA).

Mass spectrometry analysis. Differentially expressed proteins bands were excised from 1-DE gels for LC-MS/MS mass spectrometry analysis. Briefly, after the gel plug was digested with trypsin, $10 \mu 1$ of the peptide mixture was separated with a linear gradient of $5-80 \%$ buffer B [100\% acetonitrile, $0.1 \%$ formic acid (FA)] at a flow rate of $400 \mathrm{nl} / \mathrm{min}$ on a $\mathrm{C}_{18}$-reversed phase column packed in-house with Eprogen-Pur $\mathrm{C}_{18}$-AQ $5 \mu \mathrm{m}$ resin in buffer A $\left(100 \% \mathrm{H}_{2} \mathrm{O}, 0.1 \% \mathrm{FA}\right)$. A prominence nano 2D chromatography system (Shimadzu Corp., Kyoto, Japan) was coupled online to the micrOTOF-QII (Bruker Corporation, Billerica, MA, USA). The data was collected using BrukerDaltonicsmicrOTOFcontrol software 3.2 (Bruker Corporation) with the conditions $50-2,200 \mathrm{~m} / \mathrm{z}$ scan range, $1,500 \mathrm{~V}$ capillary voltages, and $150^{\circ} \mathrm{C}$ drying argon gas temperature. Finally, the selected peptide masses were analyzed using DataAnalysis software 4.1 (Bruker Corporation) and searched using the Mascot search engine version 2.3.01 (http://www.bgi-proteomics .cn/tocsam/cgi/master_results_2.pl?file=20140317\%2FF044726 .dat;pr.eh=3\%2C3p\#tc:rf:hits:3).

Western blot analysis. Following 1-DE, the gel was separately transferred to a polyvinylidene fluoride (PVDF) membrane for $90 \mathrm{~min}$ at $300 \mathrm{~mA}$ in transfer buffer $(25 \mathrm{mM}$ Tris, $0.1 \mathrm{M}$ glycine, and $20 \%$ methanol). Subsequently, the membranes were blocked for $1 \mathrm{~h}$ in TBS-Tween 20 (TBST; $0.05 \%$ Tween-20, $20 \mathrm{mM}$ Tris, $150 \mathrm{mM} \mathrm{NaCl}, \mathrm{pH}$ 7.4) containing 5\% skim milk at room temperature. After washing three times with TBS for 5 min each, the PVDF membrane was incubated with rabbit anti-human haptoglobin (catalogue no. BA3744; Wuhan Boster Biological Technology, Ltd., Wuhan, China) at a dilution of 1:200 in TBST containing 5\% skim milk at room temperature for $1 \mathrm{~h}$. The membrane was washed three times with TBS for 20 min and incubated with goat anti-rabbit IgG-horseradish peroxidase antibody (catalogue no. MBS856805; Sino-American Bio. Corp., Luoyang, China) at a dilution of 1:1,000 in TBST containing 5\% skim milk at room temperature for $40 \mathrm{~min}$. Next, the membrane was washed two times with TBS for 20 min and analyzed using the ECL Plus (Beijing Solarbio Science \& Technology Co., Ltd., Beijing, China) chemiluminescence detection method. Finally, the results were analyzed using Quantity One 4.6.2 (Bio-Rad Laboratories, Inc.).

RNA isolation and RT-qPCR analysis. Total RNA was extracted from CIKs using the RNAsimple Total RNA Kit (Tiangen Biotech Co., Ltd., Beijing, China) according to the manufacturer's protocol. A total of $1 \mu \mathrm{g}$ RNA was synthesized to cDNA using the RevertAid First Strand cDNA Synthesis kit (Thermo Fisher Scientific, Inc.) according to the manufacturer's protocol. Following cDNA synthesis, a RT-qPCR assay was performed as Livak and Schmittgen (16) reported with some modification. A segment of 141 and 221 bp was amplified using primer sets Haptoglobin-F/Haptoglobin-R (Table I) and $\beta$-actin-F/ $\beta$-actin-R (Table I), respectively. RT-qPCR was performed in a volume of $20 \mu \mathrm{l}$ containing $10 \mu \mathrm{l} 2 \mathrm{X}$ Master mix (Maxima SYBR Green/ROX qPCR Master Mix kit; Thermo Fisher Scientific, Inc.), $0.3 \mu \mathrm{l}$ of $10 \mu \mathrm{M}$ Forward Primer, $0.3 \mu \mathrm{l}$ of $10 \mu \mathrm{M}$ Reverse Primer, $0.8 \mu \mathrm{l} \mathrm{cDNA}$ and $8.6 \mu \mathrm{l} \mathrm{dH_{2 }}$ O. Next, the $20-\mu 1$ mixture was analyzed using ABI Stepone Plus (Thermo Fisher Scientific, Inc.), under the following thermocycling conditions: 1 cycle of $95^{\circ} \mathrm{C}$ for $10 \mathrm{~min}$, followed by 40 cycles of $95^{\circ} \mathrm{C}$ for $15 \mathrm{sec}, 60^{\circ} \mathrm{C}$ for $30 \mathrm{sec}$ and $72^{\circ} \mathrm{C}$ for $15 \mathrm{sec}$ and a final cycle of $60^{\circ} \mathrm{C}$ for $1 \mathrm{~min}$ and $95^{\circ} \mathrm{C}$ for $15 \mathrm{sec}$. Data were normalized according to the $2^{-\Delta \Delta \mathrm{Cq}}$ method (16). The assays were performed in three independent experiments.

Statistical analysis. The data were presented as the mean \pm standard deviation. Statistical analyses were performed using SPSS version 17.0 (SPSS, Inc., Chicago, IL, USA). Differences were determined using the Student's t-test. $\mathrm{P}<0.05$ or $\mathrm{P}<0.01$ were respectively considered to indicate significant or very significant differences. All experiments were repeated at least three times.

\section{Results}

Ratio and activity analyzed for CIKs. In order to investigate the associated protein activity of CIKs cultured in vitro, 
Table II. Identification of the differentially expressed protein in cytokine-induced killer cells using liquid chromatography-mass spectrometry.

\begin{tabular}{lcccccc}
\hline Protein & Accession name & Description & Species & Mr (Da) & pI & Trends in expression \\
\hline P43 & P00738 & Haptoglobin & Homo sapiens & 45861 & 6.13 & $\downarrow$ \\
\hline
\end{tabular}

pI, isoelectric point; Mr, molecular weight.

Table III. Matched amino acid sequences of haptoglobin (P00738) protein identified using liquid chromatography-mass spectrometry.

\begin{tabular}{lccccccl}
\hline Observed & Mr (expt) & Mr (calc) & Delta & Miss & Score & Start-end & Sequence \\
\hline 709.9410 & 1417.8673 & 1417.8181 & 0.0493 & 1 & 56 & $216-228$ & DIAPTLTLYVGKK \\
854.4398 & 1706.8649 & 1706.8120 & 0.0529 & 0 & 27 & $298-311$ & YVMLPVADQDQCIR \\
724.7164 & 2171.1274 & 2171.0504 & 0.0770 & 0 & 34 & $326-345$ & SPVGVQPILNEHTFC \\
602.3429 & 1202.6712 & 1202.6295 & 0.0417 & 0 & 42 & $392-401$ & AGMSK \\
\hline
\end{tabular}

Mr, molecular weight; expt, expected; calc, calculated.
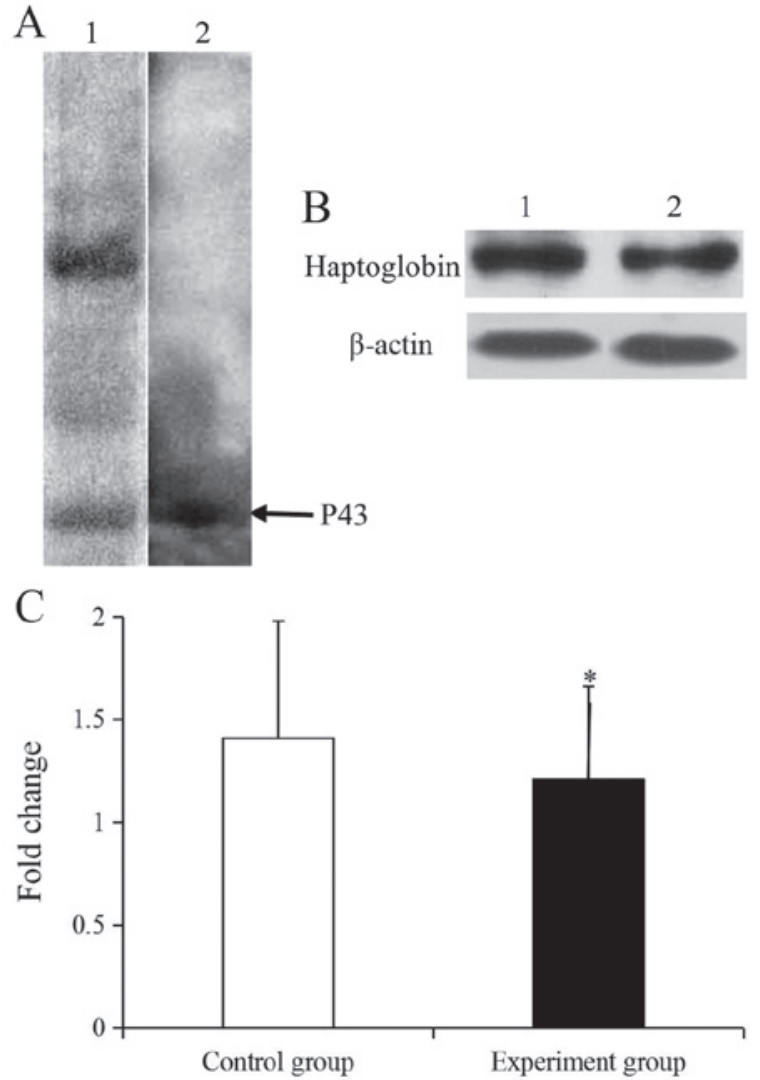

Figure 3. Identification and analysis of haptoglobin. The rabbit anti-haptoglobin (1:200) or rabbit anti- $\beta$-actin (1:200), and goat anti-rabbit IgG-horseradish peroxidase $(1: 1,000)$ were used as the primary and secondary antibodies, respectively. (A) Haptoglobin identified by 1-DE and western blotting. Lane 1, 1-DE of T cell proteins; lane 2, western blotting. (B) Western blotting of haptoglobin from T cells. Lane 1, control group; Lane 2 , experiment group for haptoglobin and $\beta$-actin. (C) The histogram analysis of gray values, gray value ratio=the gray value of haptoglobin/the gray value of $\beta$-actin. Bars represent mean \pm standard deviation. $(n=3) .{ }^{*} \mathrm{P}<0.05 .1-\mathrm{DE}$, One-dimensional gel electrophoresis.

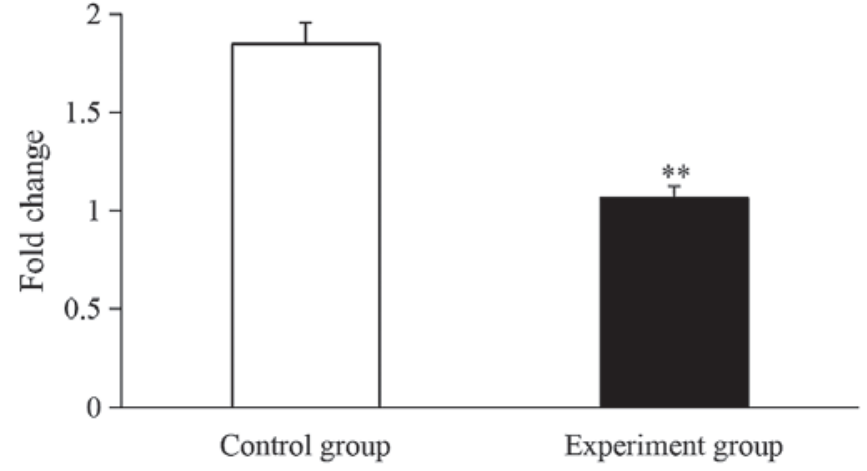

Figure 4. Reverse transcription-quantitative polymerase chain reaction analysis of haptoglobin mRNA transcripts in cytokine-induced killer cells. Haptoglobin mRNA was normalized against $\beta$-actin mRNA levels. Bars represent mean \pm standard deviation. $(n=3) .{ }^{* *} \mathrm{P}<0.01$.

gentamicin was selected as an activity inhibitor. Following stimulation, the ratio of CIKs in the control and experiment groups were 98.2 and $98.3 \%$, respectively (Fig. 1A and B). However, the activity of CIKs in the experiment group (34.3\%) was very significantly lower compared with the control group (55.2\%; P $<0.01$; Fig. 1C) because of the effect of gentamicin.

Differentially expressed protein analyzed. Based on the changes in CIK activity, an unknown differential expression protein (P43) was identified using 1-DE (Fig. 2A). As presented in Fig. 2A, the P43 molecular weight was $\sim 43 \mathrm{kDa}$, and the expression of $\mathrm{P} 43$ was significantly downregulated by 1.22-fold compared with the control group ( $\mathrm{P}<0.05$; Fig. 2B).

Identification of P43. For further investigation on the P43 protein in CIKs, the P43 foci was detected as Homo sapien 
haptoglobin protein (P00738) using LC-MS/MS (Tables II and III). As Tables II and III demonstrates, the matched amino acid sequences of haptoglobin attained an overall score of 159 , and the molecular and isoelectric point was $45861 \mathrm{Da}$, and 6.13 , respectively. Following a 1-DE separation and western blotting, the $\mathrm{P} 43$ protein in CIKs lysis was demonstrated to specifically react with the rabbit anti-human-haptoglobin (Fig. 3A). Together, these results suggested that the $\mathrm{P} 43$ protein was haptoglobin.

Haptoglobin expression analyzed. To analyze the expression of haptoglobin protein, western blotting was performed (Fig. 3). In the CIK protein, only haptoglobin could specifically reacted with rabbit anti-haptoglobin (Fig. 3A). Further investigation revealed that the expression level of b-actin in the control and experiment groups was similar and the haptoglobin was significantly downregulated by 1.17 -fold compared with the control group $(\mathrm{P}<0.05$; Fig. $3 \mathrm{~B}$ and $\mathrm{C})$.

Haptoglobin mRNA analyzed. Based on the proteomic results, a RT-qPCR assay was performed to determine the transcription levels of haptoglobin in CIKs. As presented in Fig. 4, SpHMC mRNA in the experiment group was significantly downregulated by 1.73 -fold compared with the control group $(\mathrm{P}<0.01$; Fig. 4).

\section{Discussion}

CIKs adoptive immunotherapy is used in tumor treatment due to its efficiently antitumor activity (17-20). Gentamicin is a broad-spectrum antibiotic used to preserve the aseptic culture of cells (21-23). In the present study, it was demonstrated that the CIK activity was significant inhibited by gentamicin, and further research revealed that a protein P43 was associated with CIK activity.

To determine the identity of the $\mathrm{P} 43$ protein, 1-DE with LC-MS/MC was performed (24,25). The P43 protein was successfully identified as human haptoglobin. This was similar to the findings that an unknown protein spot identified as haptoglobin in patient sera using the mass spectra strategy (26-28). For further verification of the mass spectra results, western blotting was used (29), and the results demonstrated that haptoglobin protein was specificity connected with rabbit anti-human-haptoglobin. Therefore, it was concluded that the P43 protein was haptoglobin.

Haptoglobin is a hemoglobin-binding protein expressed by a genetic polymorphism for prevented oxidative damage in plasma (30-32). However, research has identified that haptoglobin was also involved in the immune response $(33,34)$. Delanghe et al (35) demonstrated that haptoglobin phenotypes may influence $\mathrm{T}$ cells activation and effect the interplay of lymphocytes. Shen et al (36) reported that haptoglobin activates the innate immunity. Kreisel and Goldstein (37) noted that haptoglobin was a novel protein activator of the innate immune system and involved in immune modulatory as a known acute phase protein. These results demonstrated that the concentration of haptoglobin in CIKs treated with gentamicin was significantly downregulated by 1.17 using western blotting. Thus, it was deduced that the haptoglobin was associated with the enhancement of CIK activity.
To further illustrate the association of haptoglobin with CIKs activity, a quantitative RT-qPCR assay was performed. As a result, the mRNA level of haptoglobin in CIKs treated with gentamicin was significantly downregulated by 1.73 -fold compared with the control group. This is similar to the finding that haptoglobin expression signal was decreased 5.1-fold in peripheral blood mononuclear cells from healthy participants compared with methotrexate-resistant patients with rheumatoid arthritis (38). Herein, these results suggest that haptoglobin was involved in the activity-enhancement of CIKs.

In conclusion, it was identified that haptoglobin in CIKs was an activity-enhancement-associated protein. To the best of our knowledge, this is the first study to demonstrate that haptoglobin may be associated with the activity-enhancement of CIKs. Further investigation is required to explore its exact role of the signaling pathway associated with an increase in CIK activity.

\section{Acknowledgements}

The present study was supported by The Foundation of Hunan Provincial Key Laboratory for Special Pathogens Prevention and Control Foundation (grant no. 2014-5), The Hunan Province Cooperative Innovation Center for Molecular Target New Drug Study (grant no. 2015-351), and National Natural Science Foundation of China (grant no. 81101274).

\section{References}

1. Yang JC and Rosenberg SA: Adoptive T-cell therapy for cancer. Adv Immunol 130: 279-294, 2016.

2. Jäkel CE, Hauser S, Rogenhofer S, Müller SC, Brossart P and Schmidt-Wolf IG: Clinical studies applying cytokine-induced killer cells for the treatment of renal cell carcinoma. Clin Dev Immunol 2012: 473245, 2012.

3. Li R, Wang C, Liu L, Du C, Cao S, Yu J, Wang SE, Hao X, Ren $\mathrm{X}$ and Li H: Autologous cytokine-induced killer cell immunotherapy in lung cancer: A phase II clinical study. Cancer Immunol Immunother 61: 2125-2133, 2012.

4. Pan K, Guan XX, Li YQ, Zhao JJ, Li JJ, Qiu HJ, Weng DS, Wang QJ, Liu Q, Huang LX, et al: Clinical activity of adjuvant cytokine-induced killer cell immunotherapy in patients with post-mastectomy triple-negative cancer patients. Clin Cancer Res 20: 3003-3011, 2014.

5. Gammaitoni L, Giraudo L, Leuci V, Todorovic M, Mesiano G Picciotto F, Pisacane A, Zaccagna A, Volpe MG, Gallo S, et al: Effective activity of cytokine-induced killer cells against autologous metastatic melanoma including cells with stemness features. Clin Cancer Res 19: 4347-4358, 2013.

6. Pan QZ, Wang QJ, Dan JQ, Pan K, Li YQ, Zhang YJ, Zhao JJ, Weng DS, Tang Y, Huang LX, et al: A nomogram for predicting the benefit of adjuvant cytokine-induced killer cell immunotherapy in patients with hepatocellular carcinoma. Sci Rep 5: 9202, 2015.

7. Rettinger E, Kuçi S, Naumann I, Becker P, Kreyenberg H, Anzaghe M, Willasch A, Koehl U, Bug G, Ruthardt M, et al: The cytotoxic potential of interleukin-15-stimulated cytokine-induced killer cells against leukemia cells. Cytotherapy 14: 91-103, 2012.

8. Meng JX, Zhao MF, Chai X, Xiao X, Mu J, Li Q, Deng Q and Li YM: IL-21 enhances anti-leukemia effect by acting on both $\mathrm{CD}^{+} \mathrm{CD}^{2} 6^{+} \mathrm{CIK}$ cells and regulatory $\mathrm{T}$ cells derived from umbilical cord blood in vitro. Blood 122: 1051, 2013.

9. Rutella S, Iudicone P, Bonanno G, Fioravanti D, Procoli A, Lavorino C, Foddai ML, Lorusso D, Martinelli E, Vacca M, et al: Adoptive immunotherapy with cytokine-induced killer cells generated with a new good manufacturing practice-grade protocol. Cytotherapy 14: 841-850, 2012. 
10. Tan G, Zhang X, Feng H, Luo H and Wang Z: The therapeutic effect of cytokine-induced killer cells on pancreatic cancer enhanced by dendritic cells pulsed with K-Ras mutant peptide. Clin Dev Immunol 2011: 649359, 2011.

11. Ji Y, Hocker JD and Gattinoni L: Enhancing adoptive T cell immunotherapy with microRNA therapeutics. Semin Immunol 28: 45-53, 2016

12. Pan K, Li YQ, Wang W, Xu L, Zhang YJ, Zheng HX, Zhao JJ, Qiu HJ, Weng DS, Li JJ, et al: The efficacy of cytokine-induced killer cell infusion as an adjuvant therapy for postoperative hepatocellular carcinoma patients. Ann Surg Oncol 20: 4305-4311, 2013.

13. Laport GG, Sheehan K, Baker J, Armstrong R, Wong RM, Lowsky R, Johnston LJ, Shizuru JA, Miklos D, Arai S, et al: Adoptive immunotherapy with cytokine-induced killer cells for patients with relapsed hematologic malignancies after allogeneic hematopoietic cell transplantation. Biol Blood Marrow Transplant 17: 1679-1687, 2011.

14. Gao D,LiC, Xie X,Zhao P,Wei X, Sun W, Liu HC, Alexandrou AT, Jones J, Zhao R and Li JJ: Autologous tumor lysate-pulsed dendritic cell immunotherapy with cytokine-induced killer cells improves survival in gastric and colorectal cancer patients. PLoS One 9: e93886, 2014.

15. Bradford MM: A rapid and sensitive method for the quantitation of microgram quantities of protein utilizing the principle of protein-dye binding. Anal Biochem 72: 248-254, 1976.

16. Livak KJ and Schmittgen TD: Analysis of relative gene expression data using real-time quantitative PCR and the 2(-Delta Delta C(T)) method. Methods 25: 402-408, 2001.

17. Thorne SH, Negrin RS and Contag CH: Synergistic antitumor effects of immune cell-viral biotherapy. Science 311: 1780-1784, 2006.

18. Chen Y, Lin G, Guo ZQ, Zhou ZF, He ZY and Ye YB: Effets of MICA expression on the prognosis of advanced non-smal cell lung cancer and the efficacy of CIK therapy. PLoS One 8: e69044, 2013.

19. Marin V, Pizzitola I, Agostoni V, Attianese GM, Finney H, Lawson A, Pule M, Rousseau R, Biondi A and Biagi E: Cytokine-induced killer cells for cell therapy of acute myeloid leukemia: Improvement of their immune activity by expression of CD33-specific chimeric receptors. Haematologica 95: 2144-2152, 2010.

20. Zou Y, Li F, Hou W, Sampath P, Zhang Y and Thorne SH: Manipulating the expression of chemokine receptors enhances delivery and activity of cytokine-induced killer cells. Br J Cancer 110: 1992-1999, 2014.

21. Batorov EV, Shevela EY, Tikhonova MA, Batorova DS, Ushakova GY, Sizikova SA, Sergeevicheva VV, Gilevich AV, Kryuchkova IV, Ostanin AA and Chernykh ER: Mesenchymal stromal cells improve early lymphocyte recovery and T cell reconstitution after autologous hematopoietic stem cell transplantation in patients with malignant lymphomas. Cell Immunol 297: 80-86, 2015.

22. Huang J, Li C, Wang Y, Lv H, Guo Y, Dai H, Wicha MS, Chang AE and Li Q: Cytokine-induced killer (CIK) cells bound with anti-CD3/anti-CD133 bispecific antibodies target CD133(high) cancer stem cells in vitro and in vivo. Clin Immunol 149: 156-168, 2013.
23. Gargett $T$ and Brown MP: Different cytokine and stimulation conditions influence the expansion and immune phenotype of third-generation chimeric antigen receptor $\mathrm{T}$ cells specific for tumor antigen GD2. Cytotherapy 17: 487-495, 2015.

24. Zhang J, Lou X, Shen H, Zellmer L, Sun Y, Liu S, Xu N and Liao DJ: Isoforms of wild type proteins often appear as low molecular weight bands on SDS-PAGE. Biotechnol J 9: 1044-1054, 2014

25. Chehayeb JF, Robertson AP, Martin RJ and Geary TG: Proteomic analysis of adult ascaris suum fluid compartments and secretory products. PLoS Negl Trop Dis 8: e2939, 2014.

26. Othman N, Zainudin NS, Mohamed Z, Yahya MM, Leow VM and Noordin R: Protein expression in sera of patients with amoebic liver abscess (ALA): Potential use of haptoglobin as a surrogate disease marker. Trop Biomed 30: 257-266, 2013.

27. Jiang S, Lu Q, Hu S, Chen Y, Liu XL, Yang Y and Ding MP: Proteomics comparison of the sera from multiple sclerosis patients and neuromyelitis optica patients. Genet Mol Res 13: 9292-9299, 2014.

28. Felix K, Hauck O, Fritz S, Hinz U, Schnölzer M, Kempf T, Warnken U, Michel A, Pawlita M and Werner J: Serum protein signatures differentiating autoimmune pancreatitis versus pancreatic cancer. PLoS One 8: e82755, 2013.

29. Wen Q, Huang LT, Luo N, Wang YT, Li XY, Mao HP, Zhang L, Dong XQ and Yu XQ: Proteomic profiling identifies haptoglobin as a potential serum biomarker for steroid-resistant nephrotic syndrome. Am J Nephrol 36: 105-113, 2012.

30. Langlois MR and Delanghe JR: Biological and clinical significance of haptoglobin polymorphism in humans. Clin Chem 42: 1589-1600, 1996.

31. Flanagan JJ, Arjomandi A, Delanoy ML, Du Paty E, Galea P, Laune D, Rieunier F, Walker RP and Binder SR: Development of monoclonal antibodies to pre-haptoglobin 2 and their use in an enzyme-linked immunosorbent assay (ELISA). J Immunol Methods 406: 34-42, 2014.

32. Bertaggia E, Scabia G, Dalise S, Lo Verso F, Santini F, Vitti P, Chisari C, Sandri M and Maffei M: Haptoglobin is required to prevent oxidative stress and muscle atrophy. PLoS One 9: e100745, 2014

33. Vanuytsel T, Vermeire S and Cleynen I: The role of haptoglobin and its related protein, zonulin, in inflammatory bowel disease. Tissue Barriers 1: e27321, 2013.

34. Asleh R, Ward J, Levy NS, Safuri S, Aronson D and Levy AP: Haptoglobin genotype-dependent differences in macrophage lysosomal oxidative injury. J Biol Chem 289: 16313-16325, 2014.

35. Delanghe JR, Langlois MR and De Buyzere ML: Haptoglobin polymorphism: A key factor in the proatherogenic role of $B$ cells?. Atherosclerosis 217: 80-82, 2011.

36. Shen H, Song Y, Christopher CM, Wu T, Bruce C, Scabia G, Galan A, Maffei M and Daniel RG: Haptoglobin activates innate immunity to enhance acute transplant rejection in mice. J Clin Invest 122: 383-387, 2012.

37. Kreisel D and Goldstein DR: Innate immunity and organ transplantation: Focus on lung transplantation. Transpl Int 26: 2-10, 2013.

38. Tan W, Wang F, Guo D, Ke Y, Shen Y, Lv C and Zhang M: High serum level of haptoglobin is associated with the response of 12 weeks methotrexate therapy in recent-onset rheumatoid arthritis patients. Int J Rheum Dis 19: 482-489, 2016. 